\title{
METODE KOMUNIKASI DAKWAH DI MEDIA SOSIAL (FACEBOOK, YOUTUBE, TWITTER, DAN INSTAGRAM)
}

\author{
Bagus Wira Prasetia \\ STID Al-Hadid, Surabaya \\ bagus.wira.pras@gmail.com
}

\begin{abstract}
Abstrak: Pada era digital, media sosial telah menjadi media dakwah yang masif, bahkan ada organisasi dakwah yang menggerakkan para santrinya untuk ikut dakwah di media sosial. Permasalahannya ternyata ada beberapa akun tertentu yang berniat untuk dakwah namun metodenya penyampaiannya tidak tepat bahkan justru malah membuat mad'uw menjadi kurang simpatik. Misalnya adanya akun youtube yang mendakwahkan syiar Habib tertentu, namun tidak menyaring contentnya yang di dalamnya terdapat kata kotor dan ujaran kebencian sehingga ketika dilihat oleh subcribernya menjadi tidak simpatik. Melalui studi ini memberikan pandangan mengenai bagaimana metode komunikasi dakwah di media sosial. Dasar dari metode komunikasi dakwah adalah metode Al Mau'idhah Al-Hasanah (mengambil hikmah peristiwa), metode bil hikmah (persuasif) dan mujadalah (debat). Dasar metode komunikasi dakwah dihubungkan dengan karakteristik media baik secara umum maupun spesifik pada empat media sosial yang paling banyak dikonsumsi oleh masyarakat Indonesia yaitu Facebook, Youtube, Twitter, dan Instagram. Kesimpulannya bahwa aspek visual menjadi aspek penting menyampaikan pesan dakwah di media sosial. Baik itu lewat infografis, motion grafis, maupun video illustrasi. Perhatian terhadap hak cipta dan aturan UU ITE juga menjadi ciri khas dalam pemanfaatan fitur di media sosial agar komunikasi dakwah tetap efektif dan tidak terganggu dengan masalah hukum.

Keywords: dakwah, metode komunikasi dakwah, media sosial
\end{abstract}

Abstract: In digital era, social media has been a massive da'wah media. Even, there is a da'wah organization which actuates its followers to do Islamic propagation in social media. In fact, there are certain accounts which intend to propagate Islam but its method of conveying is not appropriate and even makes mad'uw unsymphatetic. For example, there is a Youtube account showing a propagation of a habib (Islamic ustadz) but does not filter its content from bad words and hate speech. It makes its subscribers unsympathetic. This study intends to provide a view about da'wah method and its ethic. The basis of its da'wah method is Al Mau'idhah Al-Hasanah (informative), bil hikmah (persuasive), and mujadalah (debate). The basis of media communication is related to both general and specific media characteristics available in four social media most consumed by Indonesians, which are Facebook, Youtube, Twitter and Instagram. It concludes that visual aspect constitutes the most significant aspect to convey da'wah message in social media through graphic info, graphic motion and illustration video. The concern on aspects of copyright and the rules of UU ITE (Consitution of Internet and Electronic Transactions) also constitutes as typical characteristics in using features in social media so that da'wah communication stay effective and is not involved in legal problem.

Key words: $d a^{\prime}$ wah, method of da'wah communication, social media 


\section{Pendahuluan}

Masyarakat telah berkembang menuju masyarakat modern yang ditandai dengan perkembangan teknologi informasi yang begitu pesat. Perkembangan teknologi informasi ini memberikan dampak yang begitu besar di segala sektor masyarakat. Baik dari sektor budaya, politik, sosial, ekonomi serta hukum. Dampak di bidang hukum misalnya, di Indonesia, ditunjukkan adanya regulasi baru yaitu undang-undang (UU ITE) yang mulai berlaku pada tahun 2008 dan kemudian mendapatkan revisi pada tahun 2016. ${ }^{1}$ Dari segi budaya, munculnya para penggemar Drakor (Drama Korea), juga menjadi bukti adanya budaya luar yang telah masuk ke dalam budaya Indonesia. ${ }^{2}$ Dan dari segi struktur sosial, muncul istilah selebgram yang mengacu pada artis yang terkenal lewat media sosial Instagram. ${ }^{3}$

Perubahan dan perkembangan ini tentu juga akan memberikan dampak kepada Dakwah Islamiyah. Dakwah Islamiyah sebagai kegiatan yang wajib bagi seluruh umat muslim, selayaknya juga perlu menyesuaikan diri terhadap perkembangan teknologi informasi ini. Masyarakat sekarang bukan hanya sekedar orang-orang yang berkumpul pada satu tempat dan waktu tertentu. Masyarakat telah berkembang menjadi orang-orang yang

\footnotetext{
1 "UU ITE Baru dan Risiko Hukum Bagi Pengguna Media Sosial," Hukumonline.com, diakses pada 9 Oktober 2018,

https://www.hukumonline.com/berita/baca/lt58636 cf3cc4d7/uu-ite-baru-dan-risiko-hukum-bagipengguna-media-sosial

2 Velda Ardia, "Drama Korea dan Budaya Popular" Jurnal Komunikasi, Volume 2, Nomor 3 (2014): 12 - 18 3 Angelica Fortuna Galuh, "Fenomena Selebgram di Indonesia", Kompasiana.com, diakses pada 9 Oktober 2018,

https://www.kompasiana.com/angelicagaluh/59cdec
}

sering berselancar di dunia maya. Bukan berarti masyarakat di dunia nyata telah hilang, namun masyarakat dunia maya ini merupakan fenomena baru dan berisi orang-orang yang bisa jadi adalah mad'uw yang memiliki prospektus untuk menjadi objek dakwah. ${ }^{4}$

Data dari We Are Social menunjukkan bahwa pengguna aktif media sosial di dunia sekarang sudah mencapai jumlah 3 milyar pengguna ${ }^{5}$. Indonesia memiliki jumlah pengguna aktif sebanyak 132 juta atau sekitar 50\% dari jumlah penduduk di Indonesia. Pengguna media sosial di Indonesia, pada tahun 2018 pertumbuhannya menempati peringkat ketiga di dunia dengan peningkatan sebanyak 24 juta pengguna atau naik sebesar 23\% dari tahun 2017. Total pada tahun 2018 ini pengguna media sosial di Indonesia sebanyak 130 juta pengguna. Angka ini merupakan angka yang sangat besar dan potensial. Baik itu untuk kepentingan pemasaran produk barang dan jasa, ataupun pemasaran produk dakwah. ${ }^{6}$

Tingginya potensi jumlah komunikan atau mad'uw ini bukan berarti selama ini diabaikan oleh para penggerak dakwah. Di Indonesia sendiri, sudah banyak akun-akun dakwah yang memberikan nilai-nilai dakwah lewat dunia internet. Tak terkecuali menyebarkan nilai-nilai dakwah lewat

8aff24054d1676df83/fenomena-selebgram-diindonesia

4 Juni Wati Sri Riski, "Dakwah dalam Masyarakat Dunia Maya (Cyber Community): Peluang dan Tantangannya" Jurnal Hikmah, Vol. VI, No. 01 (2012) : 87-95

5 Publication of We Are Social: Digital in 2018, Essential Insights Into Internet, Social Media, Mobile, And Ecommerce Use Around The World, 7.

6 Publication of We Are Social: Digital in 2018 in Southeast Asia, 34. 
media sosial, mengingat media sosial saat ini merupakan alat sosialisasi yang sangat disukai oleh banyak orang. Baik itu oleh golongan anak-anak, remaja, dewasa, hingga orang tua. Tren berdakwah melalui media sosial juga sudah berkembang. Seperti akun Instagram @fuadbakh menggunakan fitur format video, format gambar, fitur captions, fitur mentions, fitur hashtag, dan fitur comments dalam memanfaatkan instagram sebagai media untuk menyebarkan pesan-pesan islamiyah secara efektif. ${ }^{7} \quad$ Ustaz AA Gym juga berdakwah lewat media sosial (menggunakan Fanspage K.H. Abdullah Gymnastiar) menunjukkan bahwa dakwah melalui media sosial dilakukan dengan tiga bentuk, yaitu dakwah melalui tulisan, dakwah melalui gambar dan dakwah melalui video. Respon pengguna media sosial terhadap dakwah dalam media sosial cukup baik, hal ini terlihat dari banyaknya pengunjung yang menyukai dan mengomentari setiap dakwah yang diposting di media sosial. Materi dakwah yang dipost di media sosial terdiri dari materi akhlak, akidah dan syariah. ${ }^{8}$ Dari penelitian-penelitian ini, maka dapat diketahui bahwa ternyata media sosial mampu memberikan dampak positif terhadap perkembangan dakwah Islamiyah itu sendiri. Akun-akun dakwah di atas, memiliki nilai positif karena memiliki tujuan untuk menyebarkan pemikiran-pemikiran keislaman kepada masyarakat agar mereka senantiasa terjaga keimanan dan

${ }^{7}$ Anwar Sidiq, "Pemanfaatan Instagram Sebagai Media Dakwah (Study Akun @Fuadbakh)" (Skirpsi, Fakultas Dakwah Dan IImu Komunikasi Universitas Islam Negeri Raden Intan Lampung 2017), ii-iii

8 Baehaki, "Dakwah Melalui Media Sosial (Study Kasus Fanspage KH.Abdullah Gymnastiar)" (Skripsi, Fakultas Ushuluddin Dakwah Dan Adab Institut Agama Islam Negeri "Sultan Maulana Hasanuddin Banten" 2016), iii ketakwaannya. Harapannya dengan begitu nilai-nilai Islam pun akan semakin tersebar di masyarakat lewat dunia maya dan nantinya akan di implementasikan pada dunia nyata.

Dakwah lewat media sosial bukan hanya sekedar dilakukan oleh tokoh-tokoh besar. Namun juga terbuka untuk semua pengguna media sosial. Para pengguna media sosial juga memiliki hak dan kesempatan yang sama untuk juga ikut andil dalam kegiatan dakwah. Apalagi memang beberapa ustaz maupun organisasi keagamaan, banyak yang mendorong para pegiat media sosial untuk menggunakan media sosial sebagai lahan dakwah. Ustaz Abdul Somad misalnya, beliau mendorong anak-anak muda berdakwah melalui media sosial. Ulama yang merupakan alumni Kampus Al Azhar Kairo, Mesir itu menyebut dakwah anakanak muda melalui akun sosial media bernilai penting untuk menyebarkan informasi yang benar dan menyejukkan bagi umat Islam dan masyarakat pada umumnya. Ustaz Somad percaya kegiatan positif pegiat dakwah media sosial akan menjadi amal saleh di mata Allah SWT. ${ }^{9}$ Begitu pula Pengurus Lembaga Dakwah PBNU K.H. Muhammad Nur Hayid yang akrab disapa Gus Hayid mengajak para dai dan kiai NU untuk mewarnai dakwah di era digital saat ini dengan aktif menyiarkan kajian-kajian serta majelis-majelis ilmunya melalui mediamedia informasi dan teknologi yang saat ini sangat mudah untuk diakses. ${ }^{10}$ Bahkan NU

\footnotetext{
${ }^{9}$ Agung Sasongko, "UAS: Jadikan Dakwah Sosial Media Sebagai Amal Saleh" Republika.co, diakses 9 Oktober 2018, https://www.republika.co.id/berita/duniaislam/islam-nusantara/18/05/15/p8rjeh313-uasjadikan-dakwah-sosial-media-sebagai-amal-saleh 10 Muhammad Faizin, "Saatnya Kiai NU Mewarnai Dakwah di Media Sosial" nu.or.id. diakses 9 Oktober 2018 http://www.nu.or.id/post/read/88002/saatnyakiai-nu-mewarnai-dakwah-di-media-sosial
} 
pun juga menyarankan "dakwah bil medsos" bagi kalangan Nahdliyin. ${ }^{11}$ Termasuk para santri NU yang juga harus sadar akan perlunya dakwah di media sosial. $^{12}$

Hal ini tentu membuat semangat para pengguna sosial untuk juga ikut berdakwah. Apalagi dalam berdakwah, siapa pun boleh menyampaikan kebenaran walau sekedar satu ayat. Sebagaimana diriwayatkan oleh Bukhori, "Dari Abdullah bin Amr radhiyallahu ta'ala 'anhu, bahwa Nabi shallallaahu 'alaihi wa sallam bersabda: Sampaikanlah dariku walau hanya satu ayat."13 Namun terkadang para akun yang hendak berdakwah di media sosial, tidak menyadari bahwa berdakwah di media sosial tidak seperti dakwah tatap muka. Pesan yang disampaikan akan terbentur dengan asumsi-asumsi dari media sosial itu sendiri, yang sangat berbeda dengan dakwah face to face. Ada kriteria-kriteria tersendiri yang mengikat supaya dakwah dan tulisan dai bisa terpahami mad'uw

Ketika menyampaikan pesan dakwah yang di dalamnya terdapat perbedaan-perbedaan pemikiran mengenai konsep tersebut. Setiap konsep/pemikiran pasti memiliki landasan tersendiri, namun terkadang pesan tidak cukup untuk ditampung oleh media sosial, sehingga penjelasannya tidak muncul di media dakwah. Kondisi ini tentu akan membingungkan mad'uw ketika menerima

11 A Muchlishon Rochmat, "Dakwah Bil Medsos" nu.or.id diakses 9 Oktober 2018, http://www.nu.or.id/post/read/87501/dakwah-bilmedsos

12 Nahru, "Santri Milenial Sudah Saatnya Jamah Media Sosial" nu.or.id diakses 9 Oktober 2018, http://www.nu.or.id/post/read/91565/santrimilenial-sudah-saatnya-jamah-media-sosial13 Yhouga Pratama, "Sampaikan IImu Dariku Walau Satu Ayat" muslim.or.id diakses 9 Oktober 2018 pesan dakwah, apalagi ada mad'uw yang kurang sepakat atau berseberangan dengan pemikiran dari pesan dakwah tersebut. Tentu hal ini membuat media sosial menjadi ramai penuh dengan perdebatan tanpa henti. Belum lagi jika dalam pesan dakwahnya, sengaja menyinggung atau malah menyalahkan aliran lain, tentu akan menjadi sebuah perang argumen yang tidak teratur, acak, dan semrawut di media sosial.

Ada juga yang berkeinginan membuat lebih menarik dengan menggunakan metode debat, namun yang terjadi justru ketimpangan informasi. Hal ini dikarenakan metode debat dalam akun tersebut disajikan dalam bentuk dua dai yang seolah-olah berdebat, padahal tidak. Dalam kata lain, akun tersebut hanya menggabungkan dua pendapat dari video dakwah yang seolaholah saling tanya jawab. Dampaknya malah seolah-olah yang terakhir yang benar, seperti pada contoh kasus di salah satu akun youtube yang menyajikan perbedaan pendapat mengenai bidah maulid Nabi. Ada akun yang mendesain agar ketika komunikan melihat menganggap perayaan maulid nabi boleh ${ }^{14}$. Namun ada pula akun yang mendesain sebaliknya agar ketika komunikan melihat, perayaan Maulid Nabi dianggap bid'ah. ${ }^{15} \mathrm{Hal}$ ini tentu bukan hal yang baik karena memang sejatinya kedua belah pihak atau dai yang ditampilkan tidak benar-benar pernah tampil dalam satu ruang forum membahas masalah tertentu.

https://muslim.or.id/6409-sampaikan-ilmu-darikuwalau-satu-ayat.html

14 Demokrasi Indonesia "Heboh!!! Debat panas Perkara Bid'ah, Ustadz Kholid Basalamah dan Buya Yahya bedah pendapat" diakses pada 11 Oktober 2018 https://www.youtube.com/watch?v=eYE39EuJYXU

15 Muslim Channel "Heboh!!! Debat panas Perkara Bid'ah, Ustadz Kholid Basalamah dan Buya Yahya bedah pendapat" diakses pada 11 Oktober 2018 , https://www.youtube.com/watch?v=cWPhQ0QRJZg 
Akibatnya di kolom komentar, di kedua akun tersebut, saling berdebat sendiri hingga tiada arahnya.

Selain itu, ada pula menggunakan metode satu arah, namun ternyata video yang disampaikan cara pembawaan materinya kurang sesuai. Cara penyampaian atau metode penyampaian pesan, tidak bisa dipungkiri terkadang jika tidak tepat dalam memosisikannya, justru akan berdampak buruk. Pesan dakwah bisa jadi tidak sampai atau justru marah dianggap buruk oleh komunikan. Seperti contoh pada salah satu akun dakwah di youtube, yang memberikan video seorang Habib yang sedang berceramah. Dalam ceramahnya memang tampak berapi-api. Karena nadanya yang keras serta kadang juga mengeluarkan katakata kasar. Akan tetapi menjadi persoalan, beberapa komunikan menganggapnya justru baik karena dianggap tegas dan pemberani. Namun disisi lain ada pula yang menganggap bahwa dai tersebut menyulut emosi umat.$^{16}$

Berdakwah menyeru kebaikan, sebenarnya sudah dijelaskan dalam Alquran. Salah satunya yang termuat dalam surah Annahl ayat 125: "Serulah (manusia) kepada jalan Tuhanmu dengan hikmah dan pelajaran yang baik, dan bantahlah mereka dengan cara yang baik. Sesungguhnya Tuhanmu. Dialah yang lebih mengetahui tentang siapa yang tersesal dari jalanNya. dan Dialah yang lebih mengetahui orang-orang yang mendapat petunjuk." Ayat ini tentu harus bisa menginspirasi para subjek dakwah untuk bisa menempatkan diri di tengah

16 Wahid Nurdin, "Ceramah Sosok Habib ini jadi Sorotan di Medsos, Netizen : Dakwahnya seperti ini, umat mau jadi apa?" Tribunnews.com, diakses pada 8 Oktober berbagai macam perbedaan pemikiran yang ada di Indonesia.

Media sosial sesuai dengan namanya adalah media yang digunakan untuk bersosialisasi dengan orang lain. Lewat media sosial mereka saling bertukar informasi. Dari satu teman ke teman lain. Informasi ini tak terbatas pada jenis informasi tertentu namun juga dapat berbentuk informasi hiburan, berita, pendidikan, termasuk di dalamnya informasi mengenai pesan dakwah. Media sosial memiliki karakteristik sendiri mengenai pesan yang bisa dimuat maupun karakteristik komunikan dari media sosial itu sendiri. Media sosial memiliki keterbatasan durasi ataupun jumlah teks pesan tulis yang bisa dimuat. Sebagai salah satu contohnya adalah media sosial instagram yang memuat gambar dan video yang berdurasi 60 detik, pada panel caption, hanya bisa memuat 2.200 karakter saja. Batasan ini tentu membuat sebuah pesan dakwah hanya bisa disampaikan secara singkat. Sehingga jika ingin menyampaikan sebuah pesan dakwah yang kompleks, pasti akan kesulitan. Kompleks di sini maksudnya adalah pesan dakwah yang butuh pendasaran serta runtutan logika yang sangat banyak agar konsep bisa dipahami dan diyakini oleh mad'uw.

Media sosial juga memiliki komunikan yang sangat heterogen. Komunikannya yang beragam suku, beragam budaya, beragam pengetahuan, dan lain sebagainya. Komunikan media sosial juga tidak berkumpul di suatu wilayah tertentu. Hal ini membuat komunikasi di media sosial lebih

http://www.tribunnews.com/nasional/2017/10/05/c eramah-sosok-habib-ini-jadi-sorotan-di-medsosnetizen-dakwahnya-seperti-ini-umat-mau-jadi-apa 
sulit bila dibandingkan dengan komunikasi secara langsung dikarenakan tidak mengetahui secara persis komunikannya. Terutama berkaitan bagaimana pengetahuan, wawasan maupun persepsi mereka terhadap pesan dakwah yang hendak disampaikan di media sosial, dan berkenaan dengan respon komunikan.

Media sosial juga memiliki sifat yang mudah dalam menyebarkan informasi. Setiap informasi yang ada di dunia maya, sangat mudah sekali untuk disebarkan dan dikonsumsi oleh para pengguna media sosial. Namun disisi lain, hal ini juga memiliki kelemahan karena sulit untuk memverifikasi kebenaran dari informasi yang disebarkan. Hal ini kadang pula yang membuat beberapa akun dakwah menggunakan materi-materi yang kurang bisa dipertanggung jawabakan kebenarannya. Contohnya pernah tersebar di Youtube bagaimana ada seorang anak durhaka yang tubuhnya dilaknat berubah menjadi jelek wajahnya (bagaikan ikan pari). ${ }^{17}$ Lalu ada pula berita tentang bentuk perempuan yang melecehkan Alquran menjadi kerdil dan tidak sedap dipandang. ${ }^{18}$ Atau berita tentang keutamaan kabah yang akan dikelilingi oleh bulan $^{19}$. Meskipun mungkin tujuannya baik untuk memperbesar keutamaan Islam ataupun memberikan peringatan agar anak tidak durhaka, namun metode seperti ini justru merusak kebesaran Islam karena ternyata di

17 Muhammad Khairil, “(HOAX) Anak Durhaka Berubah Menjadi Ikan" Turnbackhoax.id, diakses 11 Oktober 2018, https://turnbackhoax.id/2017/02/21/hoaxanak-durhaka-berubah-menjadi-ikan/

18 Aribowo Sasmito, "[SALAH] Akibat Melecehkan Alquran Wanita ini Jadi Begini" Turnbackhoax.id diakses 11 Oktober 2018, https://turnbackhoax.id/2018/10/12/salah-akibatmelecehkan-al-quran-wanita-ini-jadi-begini/ 19 Aribowo Sasmito, "[SALAH] "Malam Nanti jam 3:25 Pagi Bulan akan Mengelilingi Ka'bah" Turnbackhoax.id diakses 11 Oktober 2018, kemudian hari ditemukan bahwa hal tersebut tidaklah benar.

Dari persoalan-persoalan yang telah dijelaskan di atas, maka tulisan ini memberikan gagasan mengenai bagaimana seharusnya metode dakwah di media sosial. Penelitian sebelumnya selama ini menghadirkan pada tataran deskripsi bahwa media sosial bisa digunakan untuk dakwah. Penelitian Nurdin yang berjudul "Spiritualising New Media: The Use of Social Media for Da'wah Purposes within Indonesian Muslim Scholars", menyampaikan bahwa sosial efektif untuk dijadikan salah satu sarana dalam berdakwah. ${ }^{20}$ Begitu pula penelitian Anwar Sidiq yang berjudul "Pemanfaatan Instagram Sebagai Media Dakwah (Study Akun @Fuadbakh)" juga mendeskripsikan bahwa media Instagram dapat dan efektif untuk berdakwah ${ }^{21}$ Begitu pula penelitian Baehaki yang berjudul "Dakwah Melalui Media Sosial (Study Kasus Fanspage K.H. Abdullah Gymnastiar)" mendeskripsikan mengenai facebook yang dijadikan sarana berdakwah. ${ }^{22}$ Penelitian Julis Suriani yang berjudul, "Komunikasi dakwah di Era Cyber" pada batas bahwa ternyata dakwah melalui media sosial bisa dilakukan, namun belum sampai mengkaji bagaimana metode komunikasi dakwah dengan menggunakan media sosial. ${ }^{23}$

https://turnbackhoax.id/2018/10/01/salah-malamnanti-jam-325-pagi-bulan-akan-mengelilingi-kabah/ ${ }^{20}$ Nurdin, "Spiritualising New Media: The Use of Social Media for Da'wah Purposes within Indonesian Muslim Scholars," Jurnal Komunikasi Islam, Volume 03, Nomor 01, Juni (2013): 1-20

${ }^{21}$ Sidiq, "Pemanfaatan Instagram."

22 Baehaki, "Dakwah Melalui."

23 Julis Suriani, "Komunikasi Dakwah di Era Cyber", Jurnal An-nida' Jurnal Pemikiran Islam, Volume 41 No. 2, Desember (2017): 252-262 
Pada tulisan ini menyajikan sebuah konsep metode komunikasi dakwah di media sosial yang sesuai dengan karakteristik tiap media sosial. Pendekatan yang digunakan adalah kualitatif, dipandu oleh konsep metode komunikasi dakwah dan konsep mengenai karakteristik media sosial. Adapun yang menjadi kajian dalam penelitian ini, dipilih 4 media sosial teratas yang paling banyak digunakan di Indonesia berdasarkan riset We Are Social tahun 2018, yaitu Facebook, Youtube, Instagram, dan Twitter. ${ }^{24}$ Teknik analisis berdasarkan Miles dan Hubberman yang meliputi tahap pengumpulan data, tahap reduksi data, dan tahap analisis data. ${ }^{25}$ Pengumpulan data dilakukan dengan cara mengumpulkan konsep-konsep yang berhubungan dengan metode komunikasi dakwah. Reduksi data dilakukan dengan cara menjadikan satu konsep-konsep yang sama agar lebih ringkas untuk ditarik prinsipnya. Pada terakhir, tahap analisis, dilakukan dengan cara menghubungkan karakteristik media sosial dengan metode komunikasi dakwah sehingga metode komunikasi dakwah bisa sesuai dengan karakteristik media sosial.

\section{Komunikasi Dakwah}

Secara bahasa, Dakwah berasal dari kata Daa yang berarti memanggil; mengundang; minta tolong kepada; berdoa; memohon; mengajak kepada sesuatu; mengubah dengan perkataan, perbuatan, dan ama..$^{26}$ Menurut Ali Aziz, dakwah memiliki tiga unsur pengertian, yaitu pertama dakwah adalah proses penyampaian akan nilai - nilai

${ }^{24}$ We are Social Southeast, 52

25 Sugiyono, Metode Penelitian Data Kualitatif dan kuantitatif, (Bandung: Alfabeta, 2012), 244

26 Abdul Basit, Filsafat Dakwah (Jakarta: PT. Raja Grafindo Persada, 2013), 43. agama Islam dari seseorang kepada orang lain. Kedua dakwah adalah penyampaian ajaran Islam tersebut dapat berupa amar ma'ruf (ajaran kepada kebaikan) dan nahi mun'kar (mencegah kemungkaran). Dan ketiga usaha tersebut dilakukan secara sadar dengan tujuan terbentuknya suatu individu atau masyarakat yang taat dan mengamalkan sepenuhnya seluruh ajaran Islam. ${ }^{27}$

Dakwah dari dasarnya adalah sebuah ajakan kebaikan. Mengajak kepada kebaikan, dapat dilakukan dengan berbagai macam cara, dapat secara paksa ataupun dengan cara persuasif. Dakwah sendiri memiliki beberapa metode untuk mencapai tujuan kebaikan tersebut. Di antaranya ada metode bil lisan, bil kalam, maupun bil haal. Pada posisi ini, komunikasi dakwah mengambil peran sebagai metode bil lisan maupun bil kalam. Yang artinya nilai-nilai dakwah disampaikan lewat sebuah pesan verbal maupun non verbal. Bukan dalam bentuk perilaku (bil haal).

Komunikasi secara etimologi berasa dari bahasa latin communis yang berarti "membuat kebersamaan" atau "membangun kebersamaan antara dua orang atau lebih". Akar kata communico yang artinya "berbagi", yang dalam hal ini artinya yang dibagi adalah pemahaman bersama melalui pertukaran pesan.$^{28}$ Sedangkan menurut Hovland, "Communication is the process by which an individual as communicator transmits stimuli to modify the behavior of other

\footnotetext{
27 Moh. Ali Aziz, Ilmu Dakwah Edisi Revisi, (Jakarta: Kencana, 2012), 1.

28 Nurani Soyomukti, Pengantar Ilmu Komunikasi, (Jogjakartaya: Az Ruz Media, 2010), 55
} 
individuals." ${ }^{29}$ Jika diartikan yaitu komunikasi merupakan suatu proses di mana seorang komunikator mengirimkan stimulus untuk mengubah perilaku dari orang lain atau komunikan.

Sesuatu disebut komunikasi jika memenuhi beberapa unsur. Menurut Harold Laswell, "(cara yang baik untuk menggambarkan komunikasi adalah dengan menjawab pertanyaan-pertanyaan berikut) Who says what and with channel to whom with what effect, "siapa yang mengatakan apa dengan saluran apa kepada siapa dengan pengaruh bagaimana." ${ }^{30}$ Jika ditarik, maka komunikasi dakwah adalah seperangkat unsur-unsur komunikasi yang memiliki hasil akhir sebagaimana tujuan dakwah. Dakwah juga memiliki unsur yang sama seperti komunikasi, yaitu dai (pelaku dakwah), mad'uw (mitra atau objek dakwah), maddah (materi dakwah), wasilah (media dakwah), thariqah (metode dakwah), dan atsar (efek dakwah).

Metode haruslah sesuai dengan karakter mad'uw, sebagaimana disampaikan oleh Toto Tasmara bahwa metode komunikasi dakwah adalah cara-cara yang dilakukan oleh seorang komunikator untuk mencapai tujuan tertentu atas dasar hikmah dan kasih sayang. Dengan kata lain, pendekatan komunikasi dakwah harus bertumpu pada suatu pandangan human oriented menempatkan penghargaan yang mulia atas diri manusia. ${ }^{31}$ Metode penyampaian pesan

29 Onong Uchjana, Ilmu Komunikasi:Teori dan Praktek, (Bandung: Rosda Karya, 2009), 31

${ }^{30}$ Deddy Mulyana, IImu Komunikasi Suatu Pengantar, (Bandung: Remaja Rosdakarya, 2010), 68-69

31 Toto Tasmara, Komunikasi Dakwah (Jakarta: Gaya Media Pratama, 1997), 43

32 Dedeh Mahmudah "Efektifitas Metode Dakwah Mauidzoh Hasanah dalam Pembinaan Akhlak Santri dakwah ini akan menimbulkan respons dan efek (atsar) pada mad'uw. Efek ini bisa berupa positif ataupun negatif bergantung proses dakwah yang terjadi. Jika metode dakwahnya sesuai, tentu hasilnya juga akan positif. Seperti metode mauidzoh hasanah untuk kalangan santri At-Taqwa Bekasi berhasil memberikan dampak positif dalam mengubah sikap dan perilaku santri. ${ }^{32}$ Begitu pula metode diskusi dan ceramah efektif untuk meningkatkan motivasi beragama pada mata pelajaran PAI siswa kelas IX di SMP 03 dan SMP 07 Kota Gorontalo. ${ }^{33}$ Sehingga dapat disimpulkan komunikasi dakwah adalah penyampaian pesan dakwah oleh seseorang yang memiliki tujuan untuk memberikan perubahan positif dari sisi keagamaan kepada komunikan dengan menggunakan media komunikasi.

\section{Metode Komunikasi Dakwah}

Metode Komunikasi dakwah secara umum ada tiga besaran. Yaitu metode bil hikmah (persuasif), metode al-mauidhah alhasanah (memberi nasihat informatif) serta metode al-mujadalah bi-al-lati hiya ahsan (dengan cara berdebat). Metode bil hikmah berasal dari kata hikmah. ${ }^{34}$ Hikmah berjalan pada metode yang realistis (praktis) dalam melakukan suatu perbuatan. Maksudnya, ketika seorang dai akan memberikan ceramahnya pada saat tertentu haruslah selalu memperhatikan realitas yang terjadi di luar, baik tingkat intelektual, pemikiran, psikologis, maupun sosial. Semua itu

At-Taqwa Putra Bekasi," (Skirpsi, Fakultas Dakwah Dan IImu Komunikasi Universitas Islam Negeri Syarif Hidayatullah Jakarta 2008), 85.

33 Abdul Rahmat "Efektifitas Metode Diskusi dan Ceramah" Jurnal Dakwah, Vol. XI No. 1 (2010): 67-87. ${ }^{34}$ Wahidin Saputra, Pengantar IImu Dakwah, (Jakarta: Raja Gafindo Persada, 2012), 244. 
menjadi acuan yang harus dipertimbangkan. ${ }^{35}$

Maka metode dakwah al-hikmah merupakan suatu metode yang dilakukan atas dasar persuasif. Adapun secara terminologi, ada beberapa pengertian hikmah di antaranya, pertama, menurut Syekh Muhammad Abduh, hikmah adalah mengetahui rahasia dan faedah di dalam tiap-tiap hal. Hikmah juga di gunakan dalam arti ucapan yang sedikit lafal tetapi banyak makna atau dapat diartikan meletakkan sesuatu pada tempat atau semestinya. Orang yang memiliki pengetahuan hikmah disebut al-hakim yaitu orang yang memiliki pengetahuan yang paling utama dari segala sesuatu. Kata hikmah juga sering dikaitkan dengan filsafat karena filsafat juga mencari pengetahuan hakikat segala sesuatu. Kedua, Toha Yahya Umar, menyatakan bahwa hikmah berarti meletakkan sesuatu pada tempatnya dengan berpikir, berusaha menyusun dan mengatur dengan cara yang sesuai keadaan zaman dengan tidak bertentangan dengan larangan Tuhan ${ }^{36}$

Dengan dasar di atas, dapat ditarik bahwa metode bil hikmah menggunakan pendekatan persuasif dan pendekatan persuasif ini, harus didasarkan pada karakteristik komunikan. Lebih detail Burgon dan Huffner menjelaskan komunikasi persuasif adalah proses komunikasi yang bertujuan mempengaruhi pemikiran dan pendapat orang lain agar menyesuaikan pendapat dan keinginan komunikator. Kedua, Proses Komunikasi

35 M. Munir, Metode Dakwah, (Jakarta: Kencana, 2009), 12-13

36 Ibid., 9.

37 Herdiyan Maulana, Psikologi Komunikasi dan Persuasi (Jakarta: Akademia Permata, 2013), 8. yang mengajak dan membujuk orang lain dengan tujuan mengubah sikap, keyakinan dan pendapat sesuai keinginan komunikator tanpa adanya unsur paksaan. ${ }^{37}$ Menurut Olson dan Zanna Persuasi di definisikan sebagai perubahan sikap akibat paparan informasi dari orang lain..$^{38}$ Untuk mencapai tujuan itu, maka harus mempertimbangkan pada argumentasi dan alasan-alasan Psikologis komunikan. ${ }^{39}$

Metode al-mauidhah al-hasanah terdiri dari dua kata yaitu mau'idzah dan hasanah. Kata mau'idzah berasal dari bahasa Arab yaitu wa'adza-ya'idzu-wa'dzan yang berarti nasehat, bimbingan, pendidikan, dan peringatan. Adapun secara terminologi, ada beberapa pengertian di antaranya, ${ }^{40}$ pertama, menurut Imam Abdullah bin Ahmad an-Nasafi yang dikutip oleh Hasanuddin, al-mau'idzatil hasanah adalah perkataan-perkataan yang tidak tersembunyi bagi mereka, bahwa engkau memberikan nasihat dan menghendaki manfaat kepada mereka atau dengan Alquran. Kedua, menurut Abd. Hamid alBilali al-mau'idzah al-hasanah merupakan salah satu manhaj (metode) dalam dakwah untuk mengajak ke jalan Allah dengan memberikan nasihat atau membimbing dengan lemah lembut agar mereka mau berbuat baik.

Dari beberapa definisi di atas, metode mau'idzah hasanah terdiri dari beberapa bentuk, di antaranya: nasehat, tabsyir watanzir, dan wasiat. Nasehat adalah salah satu cara dari al-mau'idzah al-hasanah yang

\footnotetext{
${ }^{38}$ Werner J. Severin, Teori Komunikasi Sejarah Metode dan Terapan di Dalam Media Massa, (Jakarta: Kencana Prenada Media Group, 2009),177

39 Maulana, Psikologi Komunikasi., 9.

40 M. Munir, Metode Dakwah, 16.
} 
bertujuan mengingatkan bahwa segala perbuatan pasti ada sangsi dan akibat. Tabsyir watanzir bahasa berasal dari kata basyara yang mempunyai arti memperhatikan atau merasa tenang. Tabsyir dalam istilah dakwah adalah penyampaian dakwah yang bersifat kabarkabar yang menggembirakan bagi orangorang yang mengikuti dakwah. Sedangkan wasiat dalam konteks dakwah adalah ucapan berupa arahan (taujih), kepada orang lain mengenai sesuatu yang belum dan akan terjadi (amran sayaqa mua'yan).

Metode al-mujadalah bi-al-lati hiya ahsan berasal dari etimologi lafadh mujadalah terambil dari kata "jadala" yang bermakna meminta. Apabila ditambahkan alif pada huruf jim yang mengikuti wazan faa ala, "jaa dala" dapat bermakna berdebat, dan "mujadalah" perdebatan. ${ }^{41}$ Pengertian selainnya, metode mujadalah biasa disebut metode dakwah melalui tanya jawab adalah metode yang dilakukan dengan menggunakan tanya jawab untuk mengetahui sampai sejauh pemahaman materi dakwah. Jika disederhanakan metode mujadalah ini yaitu metode debat dimana ada pihak-pihak yang bertentangan atau berseberangan secara pendapat dipertemukan untuk menentukan siapa yang menang atau kalah atau benar salah.

\section{Karakteristik Media Sosial}

Media sosial adalah new media (media baru) yang hampir mirip dengan media massa cetak dan media massa elektronik. Dimana komunikan dari new media baru ini tersebar di berbagai daerah dan bersifat anonim. Selain itu komunikan di media sosial, sudah pasti bersifat heterogen. Yang artinya komunikan memiliki berbagai macam kultur dan budaya yang beragam.

Media sosial sendiri juga memiliki beberapa karakteristik yang mungkin tidak dimiliki sebagaimana media cetak maupun media elektronik. Diantaranya adalah kemudahan dan kecepatan dalam mengakses informasi, murah, serta setiap media sosial juga memiliki fitur-fitur tertentu. Facebook memiliki segudang fitur mulai dari fitur untuk mengingatkan ulang tahun teman, mengatur privasi content, hingga membuat grup-grup yang bisa digunakan untuk menampung banyak teman dalam satu wadah grup komunikasi. Twitter yang masuk dalam kategori microblogging, memiliki ciri khas pesan yang singkat. Fitur-fitur seperti retweet, reply, like, termasuk pengaturan konten-konten terbatas ada pada media sosial ini. Instagram yang fokus pada posting gambar dan video singkat, juga memiliki fitur-fitur privasi, pembatasan konten, dan bahkan juga ada analisis beberapa karakter komunikan penonton postingan. Youtube yang fokus pada video sharing, memilik fiturfitur seperti edit didalam youtube, pembatasan konten, hingga monetisasi yang bagi sebagian orang digunakan untuk mencari mata pencaharian.

Untuk lebih detailnya, berikut beberapa fitur-fitur yang ada di keempat platform yang bisa dijadikan media komunikasi dakwah. Fitur-fitur yang ditampilkan penelitian ini adalah hasil pengamatan langsung pada media sosial tersebut. Fokus fitur dan karakteristik ini lebih ditekankan pada fitur yang bisa digunakan untuk memuat pesan, karena nantinya akan

${ }^{41}$ Saputra, Pengantar IImu., 253. 
dihubungkan dengan metode komunikasi dakwah di platform tersebut.

\section{Karakteristik Facebook}

Pada facebook, ada beberapa fitur yang bisa digunakan untuk memuat pesan, diantaranya, pertama, wall facebook (kabar beranda) yaitu fitur utama dari facebook yang bisa memuat pesan tulisan, gambar, maupun video yang disertai dengan emoticon-emoticon. Batas tulisan pada wall ini adalah 63.206 karakter dan video yang bisa dimuat berdurasi maksimal 120 menit. Pada wall facebook ini, terdapat pula beberapa setting komunikan. Seperti setting publik (yaitu semua orang dapat melihat postingan, bahkan bisa dilihat oleh orang yang tidak menggunakan facebook selama diberikan link-nya), setting hanya teman (yaitu postingan hanya bisa dilihat oleh orang yang berada dalam lingkaran teman saya), Setting khusus (yaitu postingan bisa dilihat oleh orang-orang tertentu yang kita pilih), dan setting hanya saya (yaitu postingan hanya bisa dilihat oleh pemilik akun saja).
Kedua, facebook stories yaitu fitur untuk mengopload gambar, video, tulisan, maupun gambar namun dengan durasi 20 detik dan hilang dalam waktu 24 jam. Setting komunikan pada fitur ini tergantung dari pengaturannya diantaranya setting publik (dapat dilihat oleh teman facebook, pengikut, dan orang yang mengobrol di messenger), setting teman dan koneksi (dapat dilihat oleh teman facebook dan koneksi messenger), setting teman saja (hanya teman facebook Anda yang dapat melihat cerita di aplikasi facebook dan messenger. Koneksi messenger tidak akan dapat melihat cerita), serta setting khusus (dapat memilih siapa yang dapat melihat cerita).

Ketiga, grup, yaitu fitur dimana seseorang bisa membuat grup sendiri yang teridiri dari beberapa orang yang bisa diundang untuk masuk ke dalam grup. Ada beberapa setting komunikan dari fitur grup ini, yaitu grup terbuka, grup tertutup, dan grup rahasia. Perbedaannya seperti pada tabel di bawah ini:

Tabel 1- Perbedaan Fitur Jenis Grup pada Facebook

\begin{tabular}{llll}
\hline & \multicolumn{1}{c}{ Publik } & \multicolumn{1}{c}{ Tertutup } & \multicolumn{1}{c}{ Rahasia } \\
\hline \hline $\begin{array}{l}\text { Siapa yang dapat melihat nama grup dan } \\
\text { deskripsi grup? }\end{array}$ & Siapa saja & Siapa saja & $\begin{array}{l}\text { Anggota saat ini dan } \\
\text { mantan anggota }\end{array}$ \\
\hline $\begin{array}{l}\text { Siapa yang dapat melihat postingan } \\
\text { anggota dalam grup? }\end{array}$ & Siapa saja & Anggota saat ini & Anggota saat ini \\
\hline $\begin{array}{l}\text { Siapa yang dapat menemukan grup ini } \\
\text { dalam pencarian facebook? }\end{array}$ & $\begin{array}{l}\text { Orang-orang } \\
\text { di facebook }\end{array}$ & $\begin{array}{l}\text { Orang-orang di } \\
\text { facebook }\end{array}$ & Anggota saat ini \\
\hline $\begin{array}{l}\text { Siapa yang dapat meminta untuk } \\
\text { bergabung? }\end{array}$ & $\begin{array}{l}\text { Orang-orang } \\
\text { di facebook }\end{array}$ & $\begin{array}{l}\text { Orang-orang di } \\
\text { facebook }\end{array}$ & Anggota sebelumnya \\
\hline $\begin{array}{l}\text { Siapa yang dapat melihat berita tentang } \\
\text { grup di facebook (misalnya Kabar }\end{array}$ & $\begin{array}{l}\text { Orang-orang } \\
\text { Beranda dan pencarian)? }\end{array}$ & Anggota saat ini & Anggota saat ini \\
\hline
\end{tabular}

Keempat, halaman yaitu fitur yang bisa digunakan untuk fanspage. Fitur ini banyak digunakan oleh public figure maupun perusahan-perusahaan bisnis untuk memperluas jaringan informasi. Berbeda dengan konsep pertamanan pada facebook 
yang hanya bisa berteman dengan 5.000 orang saja, dengan menggunakan halaman, jumlah pengikut di halaman facebook ini bisa tidak terbatas

\section{Karakteristik Youtube}

Pada platform youtube, pesan yang disampaikan hanya berupa video. Meskipun bisa menggunakan tulisan di kolom deskripsi sebanyak 5000 karakter, namun tulisan ini bukan menjadi content utama dari youtube. Terlebih youtube sendiri memang meneguhkan sebagai media sosial berbasis video sharing, yang artinya videolah yang menjadi pesan utama di youtube. Hal ini terlihat pula bahwa di youtube sendiri juga memiliki fitur bawaan untuk mengedit video. Meskipun fitur editnya masih pada tingkat dasar, yaitu memotong video, mengubah pengaturan video (kecerahan dan kontras, tambahkan gerakan lambat dan efek zoom pan, dan menstabilkan, audio memperbaiki atau memutar video), menambahkan filter warna, menambahkan teks ke video, menambahkan musik video, serta menambahkan transisi ke video. Karena youtube sebagai platform video sharing, maka youtube pun mampu menyediakan durasi video hingga 11 jam. Selain itu yang spesial juga di youtube adalah adanya pilihan kualitas video yang hendak kita lihat. Mulai kualitas rendah hingga kualitas tinggi. Adapun setting content youtube terdapat fitur pembatasan umur pada youtube agar tidak dapat diakses oleh anak di bawah umur. Untuk fitur komunikan berupa subscriber dimana siapapun pengguna youtube dapat menjadi subscriber-nya. Fitur komentar disetiap postingan youtube, dapat disetting terbuka ataupun close sama sekali tidak bisa diberikan komentar.

\section{Karakteristik Twitter}

Pada twitter, karena plaform ini merupakan kategori microblogging, maka fiturnya memang tidak sebanyak facebook. Bahkan jumlah tulisan yang ada di twitter pun hanya dibatasi sebanyak 280 karakter. Twitter juga dapat memuat video namun hanya pada durasi 2 menit 20 detik. Untuk setting content video ada pengaturan pembatasan umur yang bisa melihat video. Selian itu pengguna twitter bisa mengatur apakah contentnya bisa diakses publik atau hanya untuk para pengikutnya saja. Untuk komunikannya, semua orang dapat memfollow pengguna twitter (namun ada juga fitur privat dimana perlu persetujuan untuk bisa mengikuti pengguna twitter). Di twitter, ada pula fitur reply (menjawab), retweet (post ulang), like, dan share ke media lain.

\section{Karakteristik Instagram}

Pada platform instagram, sebagai media sosial yang muncul paling akhir jika dibandingkan dengan 3 platform di atas, mengusung tema berbagai foto. Namun perkembangannya video pun juga ikut dijadikan sharing content meskipun durasinya sangat terbatas, yaitu hanya 60 detik dengan maskimal 8 part setiap posting. Adapun tulisan yang bisa dimuat dalam bentuk caption atau deskripsi sebanyak 2.200 karakter. Selain lewat posting di beranda instagram, pengguna instagram juga bisa memuat content lewat instastories, yang hanya bisa bertahan selama 24 jam dan berdurasi hanya 15 detik. Komunikan pengguna instagram adalah followers-nya dengan dapat diatur privat dimana perlu persetujuan pengguna untuk bisa menjadi followersnya. Setting content post juga dibatasi lewat pembatasan umur untuk menyaring content yang sensitif untuk beberapa umur tertentu. 
Jika berbicara tentang karakteristik komunikan media sosial, perlu diketahui pula bahwa media sosial bersifat borderless tidak terikat pada wilayah. Sehingga potensi jumlah komunikannya sangat besar. Contoh lain pada media instagram misalnya ada sekitar 1 milyar pengguna aktif per Juni 2018. ${ }^{42}$ Pada facebook, ada sekitar 2.23 milyar pengguna aktif per Juli $2018{ }^{43}$, pada Twitter ada 330 juta pengguna aktif per Januari $2018^{44}$, dan pada youtube sejumlah 1,57 milyar per Januari $2018{ }^{45}$ di seluruh dunia. Di Indonesia dari 130 juta pengguna aktif media sosial per Januari 2018, 43\% menggunakan youtube, $41 \%$ menggunakan facebook, 38\% menggunakan instagram, dan $27 \%$ twitter. ${ }^{46}$

Bagaimana karakter demografis dari media sosial di Indonesia? Jika merujuk pada data yang dirilis oleh AJJ pada tahun 2015, Berdasarkan usia pengguna, mayoritas pengguna internet di Indonesia berusia 1825 tahun, yaitu sebesar hampir setengah dari total jumlah pengguna internet di Indonesia (49\%). Artinya, dapat dikatakan bahwa segmen pengguna internet di Indonesia adalah mereka yang termasuk ke dalam kategori 'digital natives'. ${ }^{47}$ Digital

42 Josh Constine, "Instagram hits 1 Billion Monthly Users, up from 800M in September" techcrunch.com diakses $10 \quad$ Agustus 2018, https://techcrunch.com/2018/06/20/instagram-1billion-users/

43 "Top 15 Valuable Facebook Statistic" zephoria.com diakses 10 Agustus 2018, https://zephoria.com/top15-valuable-facebook-statistics/

${ }^{44}$ Salman Aslam, "Twitter by the Numbers: Stats, Demographics \& Fun Facts" omnicoreagency.com, $\begin{array}{llll}\text { diakses } & 10 & \text { Agustus } & 2018\end{array}$ https://www.omnicoreagency.com/twitter-statistics/ 45 Salman Aslam, "Youtube by the Numbers: Stats, Demographics \& Fun Facts" omnicoreagency.com $\begin{array}{llll}\text { diakses } & 10 & \text { Agustus } & 2018\end{array}$ https://www.omnicoreagency.com/youtubestatistics/ natives adalah generasi muda yang lahir saat internet telah menjadi bagian hidup mereka. ${ }^{48}$ Namun pada publikasi pada tahun 2016, hasil survei terbaru menunjukkan pengguna internet (bukan media sosial saja), $18,4 \%$ berusia $10-24$ tahun, $24.4 \%$ berusia 25-34 tahun, $29.2 \%$ berusia 35-44 , 10\% berusia 55 tahun ke atas. ${ }^{49}$ Meskipun ada perbedaan hasil survei, namun jumlah di atas adalah jumlah pengguna internet secara keseluruhan. Tidak hanya media sosial. Jika di detailkan dalam bentuk media sosial, jumlah pengguna facebook di Indonesia pada tahun 2018 ini 35\% nya berumur 18-24 tahun, kemudian disusul umur 25-34 tahun sebanyak 30\%, dan anak usia 13-17tahun sebanyak $18 \%{ }^{50}$. Untuk pengguna instagram di Indonesia tahun 2017, sebagai mana dikutip dari website Napoleon (website penyedia analisis media sosial), 40\% remaja berumur 18-24 tahun, 27\% dewasa berumur 25-34 tahun, serta urutan ketiga anak-anak usia 13-17 tahun sebanyak $13 \% .^{51}$

Untuk demografis pengguna twitter dan youtube, belum ada data yang merilis mengenai demografis para penggunanya. Dari data demografis yang dipaparkan, kemungkinan besar penggunanya adalah

\footnotetext{
${ }^{46}$ We are Social Southeast, 52

47 Asosiasi Penyedia Jasa Internet Indonesia, Profil Pengguna Internet Indonesia 2014, (Jakarta: Asosiasi Penyelenggara Jasa Internet Indonesia,2015), 12.

${ }^{48}$ Helsper, Ellen and Eynon, Rebecca, "Digital Natives: Where is the Evidence?" British Educational Research Journal (2009): 1.

49 Asosiasi Penyedia Jasa Internet Indonesia 2016, Infografis: Penetrasi \& Perilaku Pengguna Internet Indonesia (Jakarta: Asosiasi Penyelenggara Jasa Internet Indonesia, 2016), 7

50 We are Social Southeast, 54.

51 "Instagram User Demographics in Indonesia March 2017" napoleoncat.com, diakses 10 Agustus 2018 https://napoleoncat.com/blog/en/instagramuser-demographics-in-indonesia-march-2017/
} 
anak-anak dan remaja yang masih dalam proses mencari jati diri serta emosi yang masih labil.52 Karakteristik komunikan seperti ini menjadi asumsi, bahwa informasiinformasi yang diterima lewat media sosial, akan mudah ditelan oleh mereka. Hal ini dikarenakan tingkat kognisi dan pematangan hidup yang masih belum banyak. Karena itulah ketika sebuah informasi yang diberikan berupa informasi yang negatif, maka tentu hasilnya juga akan negatif bagi para konsumen media. Terutama para penggunaannya adalah para kalangan remaja. Ketika sebuah informasi yang disajikan berbelit, atau butuh banyak wawasan, hal ini juga menjadi masalah. Akhirnya pesan tidak bisa sampai dengan baik. Terlebih data dari Central Connecticut State University (CCSU) tahun 2016 menunjukkan bahwa tingkat literasi masyarakat Indonesia masih minim. ${ }^{53}$

Selain karakteristik media sosial dalam memuat content serta karakteristik demografi komunikannya, ada satu karakteristik lagi yang perlu diperhatikan nantinya kaitannya dengan regulasi media sosial di Indonesia. Hal ini juga menjadi salah satu karakteristik dari media sosial di Indonesia. Adapun regulasi ini jika di Indonesia diatur pada Undang-Undang nomor 11 tahun 2008 tentang Informasi dan Transaksi Elektronik (ITE) yang diperbaharui dengan UU 19 Tahun 2016. Adapun beberapa content yang dilarang dalam UU ITE ini adalah: (a)memiliki muatan yang melanggar kesusilaan; (b) memiliki muatan perjudian; (c) memiliki muatan penghinaan dan/atau pencemaran nama baik; (d) memiliki muatan pemerasan

52 Lidya Sayidatun Nisya \& Diah Sofiah. "Religiusitas, Kecerdasan Emosional Dan Kenakalan Remaja." Jurnal Psikologi, Volume 7 No. 2,(Agustus, 2012): 579. dan/atau pengancaman; (e) berita bohong dan menyesatkan yang mengakibatkan kerugian konsumen dalam Transaksi Elektronik; (f) menimbulkan rasa kebencian atau permusuhan individu dan/atau kelompok masyarakat tertentu berdasarkan atas suku, agama, ras, dan antargolongan (SARA); (g) berisi ancaman kekerasan atau menakutnakuti yang ditujukan secara pribadi.

Selain tentang isi content dalam UU ITE, karena media sosial adalah media sharing, maka terkadang dimungkinkan untuk share ataupun repost suatu karya. Untuk itu perlu juga diperhatikan karakteristik tentang penggunaan hak cipta. Di platform seperti youtube maupun instagram, postingan dapat dilaporkan karena melanggar hak cipta dari pencipta karya. Untuk itu pada media sosial pun, harus memperhatikan mengenai dari mana content yang kita ciptakan. Apakah buatan sendiri, ataukah dari hasil olah miliki orang lain. Jika milik orang lain, apakah memiliki hak cipta, ataukah tidak.

Karakteristik yang juga ada di semua media sosial adalah fitur hastagh (\#) yang menghubungkan tema-teman content yang sama dalam dunia maya dan media sosial. Karakteristik ini juga menjadi ciri khas media sosial yang tidak ada di media cetak maupun media elektronik. Fitur ini akan membantu para dai untuk menyesuaikan tema content yang hendak dibuat. Sedangkan untuk mad'uw akan terbantu untuk mencari

\footnotetext{
53 "World's Most Literate Nations Ranked" webcapp.ccsu.edu, diakses 10 Agustus 2018 https://webcapp.ccsu.edu/?news=1767\&data
} 
informasi mengena tema pesan dakwah yang serupa.

\section{Metode Komunikasi Dakwah di Media Sosial}

Berdasarkan konsep metode komunikasi dakwah serta karakteristik-karakteristik dari media sosial, maka berikut metode komunikasi dakwah di media sosial. Untuk mempertajam, maka analisisnya disajikan per media sosial dalam empat platform, yaitu facebook, youtube, twitter, dan instagram.

\section{Metode Komunikasi Dakwah di Media Sosial Facebook}

Melihat banyaknya fitur yang ada dalam media sosial facebook, tiga metode komunikasi dakwah dapat diterapkan dalam media sosial facebook. Baik itu metode bil hikmah (persuasif), metode al mauidhah alhasanah (memberi nasihat informatif) serta metode al-mujadalah bi-al-lati hiya ahsan (dengan cara berdebat). Metode bil hikmah, metode ini mengutamakan komunikasi persuasif, bisa menggunakan fitur posting wall facebook dan fitur halaman. Fitur facebook stories kurang tepat untuk digunakan sebagai metode komunikasi bil hikmah karena kapasistas tampungan hanya 20 detik. Terlalu singkat untuk dapat mempersuasif. Metode komunikasi melalui fitur posting wall dan halaman ini ditekankan pada bagaimana pesan yang disampaikan menggunakan dominasi pendekatan visual. Kenapa penekannnya visual, baik itu gambar maupun video? Hasil riset We Are Social bahwa masyarakat Indonesia memiliki engagement pada Facebook dengan video post $9,70 \%$, picture post $8.55 \%$, dan post status tulis hanya $4,65 \%{ }^{54}$. Hal ini membuktikan bahwa metode komunikasi dengan menggunakan pesan dakwah yang didominasi oleh pesan visual, akan memberikan share lebih banyak dan akan lebih banyak menarik mad'uw di media sosial Facebook. Maka selayaknya pesan-pesan dakwah yang disampaikan bisa dibungkus lewat pesan gambar ataupun video. Dengan begitu komunikasi menjadi lebih efektif kepada para komunikan mad'uw nya. Apakah kemudian dakwah menggunakan tulisan tidak bagus di facebook?

Jika melihat kapasitas dari facebook dalam menampung pesan tulisan, dakwah lewat tulisan masih dimungkinkan. Namun tulisan ini harus diupayakan bagaimana tulisan di facebook ini bisa menarik atau mempersuasi para komunikan. Jika dilihat dari karakteristik psikologis komunikan, dimana komunikan dari facebook $50 \%$ lebih komunikannya berumur kurang dari 25 tahun, maka dalam upaya mempersuasi ini memang akan lebih bagus jika tidak mengandalkan tulisan semata. Artinya jika menggunakan tulisan dalam menyampaikan pesan dakwah, gunakan juga gambar yang relevan untuk mendukung tulisan yang ada dalam wall. Sehingga ketika posting, bukan hanya tulisan semata yang tampil. Dengan adanya gambar ini, maka komunikan sebagian besar masih berada di bawah umur 25 tahun, akan terpersuasif dengan adanya pesan nonverbal lewat visualisasi tersebut.

Agar lebih menarik, pesan yang disampaikan bisa dibungkus dalam bentuk infografis dalam bentuk foto maupun motion grafis dalam bentuk video. Pesan seperti ini sangat

54 We Are Social, 56 
pas dengan metode komunikasi bil hikmah yang lebih menekankan pada persuasif. Pada postingan wall, perlu diseting publik agar semua komunikan bisa menikmati content dakwah kita. Begitu pula ketika memposting di halaman facebook. Karena dominasi gambar dan video, maka perlu diperhatikan juga mengenai hak cipta. Apakah postingan melanggar hak cipta atau tidak. Selain itu juga diperhatikan apakah content yang disampaikan melanggar UU ITE atau tidak.

Metode al-mauidhah al-hasanah bisa dioptimalkan lewat facebook stories, posting wall, dan juga halaman facebook. Facebook stories fokus pada penggunaan metode mauidhah hasanah yang berbentuk motivasional informatif. Namun untuk penggunaan mauidhah hasanah yang berbentuk nasihat yang mengambil hikmah dari suatu peristiwa, maka dioptimalkan dengan menggunakan posting wall dan halaman karena dibutuhkan space yang banyak untuk memuat peristiwa yang hendak dijadikan hikmah. Penggunaan peristiwa ini tentu juga akan mempergunakan content-content eksternal untuk menunjang. Seperti link berita maupun data penunjang berupa video atau foto peristiwa. Maka dari itu perlu diperhatikan pula mengenai hak cipta dari sumber contentnya.

Selain itu perlu di ingat bahwa sebagian besar komunikan dari facebook adalah orang dibawah 25 tahun. Yang artinya masih banyak juga anak-anak. Untuk itu ketika memuat gambar atau video peristiwa, perlu diperhatikan pula apakah contentnya sensitif terhadap anak-anak. Misalnya foto atau video tentang bencana. Maka perlu diperhatikan apakah ada gambar korban yang berdarah-darah. Karena gambar seperti ini tidak sesuai psikologis anak-anak. Terakhir, penggunaan hastagh juga diperlukan agar pesan facebook bisa terhubung dengan tema-tema yang sama di dunia maya.

Metode al-mujadalah bi-al-lati hiya ahsan (dengan cara berdebat) di media facebook, hanya digunakan pada fitur grup. Metode debat dimana dua pemikiran bertemu, harus disajikan dalam bentuk yang proporsional dengan memberikan kesempatan yang sama antar pihak yang saling berseberangan. Untuk itu, hanya fitur gruplah yang sesuai untuk membawakan metode dakwah dalam menyiarkan pesan dakwah. Mengapa demikian?

Pada fitur grup, admin grup bisa mengontrol orang-orang yang memposting ataupun berkomentar menanggapi tema-tema yang diperdebatkan. Dengan begitu jalannya debat akan lebih teratur jika dibandingkan membawakan pesan debat yang akhirnya membawa perdebatan di kolom komentar wall facebook ataupun halaman facebook. Selain itu admin juga bisa mengatur komentar ataupun tanggapan yang bertentangan dengan UU ITE. Fitur-fitur inilah yang bisa membuat pihak-pihak yang ingin berdiskusi atau berdebat, tidak perlu khawatir akan tumpang tindih tulisan, karena admin bisa memberikan sebuah aturan dalam grup tentang bagaimana diskusi atau debat akan berlangsung. Dengan begitu, setiap pihak dapat menyampaikan argumentasi masing-masing tanpa harus terganggu oleh postingan komentar orang lain. Asumsinya tentu pemilik grup adalah orang yang benar-benar ingin menyampaikan pesan dakwah lewat pendekatan debat. Bukan pemilik grup yang 
sengaja ingin menjatuhkan pihak lain sehingga ada ketidakadilan dalam pengelolaan grup. Pada fitur grup ini, juga perlu diperhatikan dalam menerima komunikan yang hendak masuk di grup. Jika dirasa masih anak-anak, alangkah baiknya tidak dimasukkan dalam grup perdebatan karena ditakutkan kognisi anak-anak masih belum bisa mencerna dengan baik. Terlebih komunikan anak-anak di facebook jumlahnya juga lumayan besar. Sehingga perlu diaktifkan fitur konfirmasi penerimaan anggota grup.

\section{Metode Komunikasi Dakwah di Media Sosial Youtube}

Video sharing adalah fokus utama pada media sosial youtube. Maka metode komunikasi dakwah lewat media social youtube, lebih ditekankan pada pengguanan metode bil hikmah maupun mauidhah hasanah. Mengapa demikian? Karena fitur yang ada di youtube cenderung satu arah dan tidak bisa menyambungkan dua pihak yang saling berseberangan. Metode bil hikmah di youtube, hampir sama dengan pada facebook, bisa menggunakan motion grafik atau illustrated video (yaitu pesan dakwah yang disertai ilustrasi video dari pesan dakwah yang disampaikan) sebagai alternatif penyampaian pesan yang ada di youtube. Sehingga yang ditampilkan tidak sekedar menampilkan video para dai yang sedang ceramah saja. Akan terkesan monoton dan kurang menarik. Apalagi para pengguna youtube mencari youtube karena videonya. Untuk itu semakin menarik video, tentu juga akan semakin menarik mad'uw juga.

Karena di youtube ada fitur editing juga, maka selayaknya dalam menggunakan bil hikmah, musik pun juga harus menjadi salah satu unsur yang harus diperhatikan. Artinya persuasif pesan dakwah disampaikan dengan didukung musik atau instrumen yang sesuai. Hal ini tentu akan menambah daya persuasif pesan dakwah di youtube. Untuk pesan mauidhah hasanah ketika memberikan peristiwa sebagai salah satu sumber content, maka perlu juga peristiwa disajikan dalam bentuk video. Bukan hanya sekedar gambar foto yang dibuat bergerak. Voice over atau narator dalam menjelaskan peristiwa, sebisa mungkin memiliki suara yang enak didengar. Hal ini akan membuat pesan nasehat akan jauh bisa masuk di dalam kalbu. Yang tak kalah penting, perlu juga sekirannya menyeting pembatasan umur pemirsa jika menggunakan peristiwa yang ada content yang kurang layak untuk dilihat untuk anak-anak.

Baik metode bil hikmah dan mauidhah hasanah, karena di youtube memiliki fitur memotong video, maka selayaknya ketika membuat content video di youtube juga harus sudah disaring mengenai perkataanperkataan yang itu bertentangan dengan UU ITE. Sehingga harapannya pesan dakwah di youtube tidak ternodai oleh perkataanperkataan yang justru membuat mad'uw menjadi merasa tidak nyaman dengan apa yang ditampilkan di video youtube.

\section{Metode Komunikasi dakwah di Media Sosial Twitter}

Microblogging ini banyak sekali di dalamnya juga diwarnai dengan perdebatan. Fitur reply dan mentionnya, bisa dijadikan untuk saling menghubungkan antara dua pihak yang saling berseberangan. Baik itu dalam bidang dakwah maupun bidang selainnya. Oleh sebab itu metode al-mujadalah bi-allati hiya ahsan pada media sosial twitter memang lebih terbuka. Artinya siapa saja 
bisa berdebat tentang konsep keislaman. Namun kelemahan di twitter lewat fitur-fitur ini adalah tidak ada pihak penengah atau moderator. Akhirnya bisa juga terjadi debat kusir yang tidak ada batasanya. Belum lagi jika yang mereplay banyak akun. Maka bisa jadi hampir sama seperti kolom komentar, bisa tidak teratur. Untuk itulah metode debat di twitter ini dalam konteks komunikasi dakwah, kurang efektif untuk mencapai pemahaman keagamaan.

Efektifas penggunaan dari media twitter lebih kuat dalam hal bil hikmah dan mauidhah hasanah. Bagaimana membawakan bil hikmah dan mauidhah hasanah ini di media twitter? Karena pesannya yang cukup sedikit yang bisa ditampung, baik itu video maupun tulisan, maka tekniknya benar-benar menggunakan pendekatan visual dan kata-kata singkat. Gambar infografis serta penggunaan kutipan (quotes), menjadi metode yang paling pas untuk menyiarkan pesan dakwah di media twitter. Menggunakan tulisan yang berteletele tidak sesuai dengan karakteristik twitter yang menggunakan pesan yang singkat. Meskipun ada fitur lain seperti crhipstory yang bisa menampung banyak tulisan, namun sebagian besar pengguna twitter menginginkan pesan yang padat dan singkat.

Yang menjadi ciri khas di twitter adalah kekuatan hastaghnya. Oleh karena itu, penggunaan metode bil hikmah dan mauidhah hasanah, apapun pesannya, wajib menyertakan hastagh yang sesuai dengan tema. Akan lebih bagus ketika yang dibahas adalah tema-tema yang sedang trending topic. Hal ini akan membantu pendakwah menyampaikan pesan dakwah kepada banyak mad'uw lewat media twitter. Selain itu tentu aturan content di UU ITE dan hak cipta, tetap harus diperhatikan dalam menggunakan content di media sosial twitter.

\section{Metode Komunikasi Dakwah di Media Sosial Instagram}

Instagram yang berfokus pada photos dan short video sharing, menjadikan metode komunikasi dakwah di media ini pun juga berfokus pada bagaimana menyajikan pesan dakwah dengan pendekatan visual. Meskipun tetap bisa menggunakan pendekatan tulisan dengan batas caption 2.200 karakternya. Namun jika dilihat dari motivasi para pengguna instagram yang inign mencari sebuah pesan visual, maka pesan visual ini juga menjadi perhatian dalam menggunakan media sosial instagram untuk kepentingan dakwah.

Metode komunikasi dakwah lewat mujadalah, pada media instagram tidak bisa digunakan. Hal ini dikarenakan tidak ada fitur di media instagram dalam menggabungkan antara dua belah pihak yang saling berseberangan pendapat untuk masuk pada satu forum tertentu. Maka metode komunikasi dakwah di media instagram cendrung menggunakan metode komunikasi dakwah bil hikmah dan mauidhah hasanah. Lalu bagaimana menerapkan metode bil hikmah di media Instagram?

Durasi video yang pendek, menjadikan komunikasi bil hikmah atau persuasif di media instagram akan lebih efektif jika menggunakan gambar atau foto. Jikapun menggunakan video, maka harus menggunakan short video (video pendek) yang berdurasi kurang dari 1 menit atau maksimal 8 menit karena tiap posting bisa 
mempost 8 foto atau video sekaligus. Namun kelemahan penggunaan 8 menit ini adalah adanya potongan posting ketika melihat. Atau dalam kata lain, tidak bisa terus berlanjut lancar melihat video selama 8 menit karena harus menggeser post. Dan terkadang juga potongan video ada yang hilang saat dilihat pada tiap post tersebut.

Oleh sebab itu alternatif penggunaan metode bil hikmah di media instagram ini bisa menggunakan infografis maupun infografis dan illustrated video namun dengan durasi yang tidak terlalu panjang. Bisa juga dengan menggunakan quotesquotes yang ditempelkan pada foto yang sesuai dengan pesan quotes-nya (picture quotes). Dengan metode ini, ajakan kebaikan dakwah bisa lebih mempengaruhi mad'uw karena ditunjang dengan gambar dan video yang menarik. Dan juga jangan lupa untuk memperhatikan aspek hak cipta jika ingin mengambil atau me-repost karya orang lain. Hastagh pad caption juga harus disertakan agar mad'uw dari pesan dakwah yang disampaikan dapat tersebar lebih luas karena terhubung dengan pesan dakwah yang memiliki tema yang sama.

Metode mauidhah hasanah yang menekankan pada peristiwa untuk dijadikan hikmah, digunakan di instagram dengan menggunakan gabungan antara video peristiwa dan caption. Juga bisa menggunakan voice over (suara narator) pada video peristiwa yang hendak dijadikan hikmah sehingga bisa membuat komunikan menangkap visual dan audio pesan hikmah secara bersamaan. Namun yang perlu diperhatikan juga, ketika menggunakan video peristiwa yang kurang baik untuk anak-anak atau mengandung content yang agak sensitif (misalnya: ada gambar darah berceceran), maka perlu memberikan batasan pemutaran video agar lebih nyaman pada mad'uw yang sensitif terhadap hal-hal yang kurang layak untuk dilihat.

\section{Kesimpulan}

Metode dakwah ketika masuk dalam konteks media sosial, memiliki ciri khas tersendiri. Karakteristik media sosial ini, baik itu berkaitan dengan fitur-fitur yang ada di media sosial, keterbatasan yang ada di dalam media sosial, komunikan pengguna media sosial, maupun aturan hukum yang mengikat di media sosial, membuat metode komunikasi dakwah di media sosial tidak sama ketika bertemu secara face to face. Facebook yang memiliki jaring sosial yang luas serta memiliki banyak fitur, bisa digunakan untuk membawakan metode mujadalah lewat fitur grupnya. Dimana lewat fitur ini, dua pihak berseberangan bisa dipertemukan dalam satu bentuk forum dunia maya. Dengan pemilik grup sebagai moderator, maka keteraturan debat dapat dilakukan. Selain itu mauidhah hasanah dan bil hikmah menggunakan fitur halaman untuk menyampaikan pesan informatif dan persuasif yang lebih masif dengan desain visual menjadi perhatian utama.

Metode komunikasi dakwah bil hikmah dan mauidhah hasanah pada twitter sebagai microblogging, diwujudkan dalam bentuk inforgrafis maupun qutoes-quotes singkat. Hastagh sebagai salah satu fitur yang paling kuat pada twitter, menjadi hal wajib yang harus dituliskan disetiap pesan dakwah yang dimuat di twitter. Pada media Youtube, sebagai media sosial video sharing diwujudkan dalam bentuk motion grafis dan illustrated video dan bisa mengandalkan video editing yang ada di youtube untuk 
menyaring content yang tidak sesuai dengan aturan UU ITE. Instagram sebagai photo dan short video sharing, metode bil hikmah dan mauidhah hasanah terimplementasi lewat penggunaan infografis, short illustrated videos, serta picture quotes.

\section{Bibliografi}

Ali Aziz, Moh. Ilmu Dakwah Edisi Revisi, Jakarta: Kencana, 2012

Ardia, Velda. "Drama Korea dan Budaya Popular" Jurnal Komunikasi, Volume 2, Nomor 3 (2014) : $12-18$

Aslam, Salman. "Twitter by the Numbers: Stats, Demographics \& Fun Facts" Agustus 10,2018. https://www.omnicoreagency.com/twitter-statistics/

Aslam, Salman "Youtube by the Numbers: Stats, Demographics \& Fun Facts" "World's Most Literate Nations Ranked" https://webcapp.ccsu.edu/?news=1767\&data https://www.omnicoreagency.com/youtube-statistics/

Asosiasi Penyedia Jasa Internet Indonesia 2016, Infografis: Penetrasi \& Perilaku Pengguna Internet Indonesia 2016

Baehaki, "Dakwah Melalui Media Sosial (Study Kasus Fanspage KH.Abdullah Gymnastiar)". Skripsi, Fakultas Ushuluddin Dakwah Dan Adab Institut Agama Islam Negeri "Sultan Maulana Hasanuddin Banten", 2016.

Basit, Abdul. Filsafat Dakwah, Jakarta: PT Raja Grafindo Persada, 2013

Channel, Muslim “Heboh!!! Debat Panas Perkara Bid'ah, Ustadz Kholid Basalamah dan Buya Yahya Beda Pendapat" Oktober, 11, 2018. https://www.youtube.com/watch?v=cWPhQ0QRJZg

Constine, Josh "Instagram hits 1 billion monthly users, up from 800M in September" Agustus 10,2018. https://techcrunch.com/2018/06/20/instagram-1-billion-users/

Faizin, Muhammad. "Saatnya Kiai NU Mewarnai Dakwah di Media Sosial”oktober, 9, 2018. http://www.nu.or.id/post/read/88002/saatnya-kiai-nu-mewarnai-dakwah-di-mediasosial

Fortuna, Angelica Galuh. "Fenomena Selebgram di Indonesia", diakses pada 9 Oktober 2018, https://www.kompasiana.com/angelicagaluh/59cdec8aff24054d1676df83/fenomena -selebgram-di-indonesia

Haris, Abd. Pengantar Etika Islam, Sidoarjo: Al-Afkar, 2007

Helsper, Ellen and Eynon, Rebecca, Digital Natives: Where is the Evidence? British educational research journal : 2009

Indonesia, Demokrasi. "Heboh!!! Debat panas Perkara Bid'ah, Ustadz Kholid Basalamah dan Buya Yahya Beda Pendapat" Oktober, 11, 2018. https://www.youtube.com/watch?v=eYE39EuJYXU

"Instagram user demographics in Indonesia - March 2017" Agustus 10,2018. https://napoleoncat.com/blog/en/instagram-user-demographics-in-indonesiamarch-2017/

J, WernerSeverin, Teori Komunikasi Sejarah Metode dan Terapan di Dalam Media Massa. Jakarta: Kencana Prenada Media Grup, 2009 
Khairil, Muhammad. " (HOAX) Anak Durhaka Berubah Menjadi Ikan” Oktober 11, 2018. https://turnbackhoax.id/2017/02/21/hoax-anak-durhaka-berubah-menjadi-ikan/

Mahmudah, Dedeh. "Efektifitas Metode Dakwah Mauidzoh Hasanah dalam Pembinaan Akhlak Santri At-Taqwa Putra Bekasi”, Skirpsi, Fakultas Dakwah Dan IImu Komunikasi Universitas Islam Negeri Syarif Hidayatullah Jakarta, 2008

Muchlishon, A Rochmat, "Dakwah Bil Medsos" Oktober, 9, 2018. http://www.nu.or.id/post/read/87501/dakwah-bil-medsos

Mulyana, Deddy. IImu Komunikasi Suatu Pengantar, Bandung: PT. Remaja Rosdakarya, 2010 Munir, Muh. Metode Dakwah, Jakarta: Kencana, 2009

Maulana, Herdiyan. Psikologi Komunikasi dan Persuasi. Jakarta: Akademia Permata Nahru. "Santri Milenial Sudah Saatnya Jamah Media Sosial" Oktober, 9,2018. http://www.nu.or.id/post/read/91565/santri-milenial-sudah-saatnya-jamah-mediasosial-

Nurdin, "Spiritualising New Media: The Use of Social Media for Da'wah Purposes within Indonesian Muslim Scholars," Jurnal Komunikasi Islam, Volume 03, Nomor 01, Juni (2013) : 1-20

Nurdin, Wahid. "Ceramah Sosok Habib ini jadi Sorotan di Medsos, Netizen : Dakwahnya seperti ini, umat mau jadi apa?" Oktober, 8, 2018.

http://www.tribunnews.com/nasional/2017/10/05/ceramah-sosok-habib-ini-jadisorotan-di-medsos-netizen-dakwahnya-seperti-ini-umat-mau-jadi-apa

Pratama, Yhouga. "Sampaikan IImu Dariku Walau Satu Ayat" Oktober, 9, 2018. https://muslim.or.id/6409-sampaikan-ilmu-dariku-walau-satu-ayat.html

Rahmaniyah, Istigfarotur. Pendidikan Etika Konsep Jiwa dan Etika Prespektif Ibnu Maskawaih, Malang: Aditya Media, 2010

Rahmat, Abdul. "Efektifitas Metode Diskusi dan Ceramah", JURNAL DAKWAH, Vol. XI No. 1, (2010) : 67-87

Saputra, Wahidin. Pengantar Ilmu dakwah, Jakarta: Raja Gafindo Persada, 2012

Sasmito, Aribowo " [SALAH] "akibat melecehkan al.quran wanita ini jadi begini" Oktober 11, 2018. https://turnbackhoax.id/2018/10/12/salah-akibat-melecehkan-al-quranwanita-ini-jadi-begini/

Sasmito, Aribowo "[SALAH] "Malam nanti jam 3:25 pagi bulan akan mengelilingi Ka'bah" Oktober 11, 2018. https://turnbackhoax.id/2018/10/01/salah-malam-nanti-jam-325pagi-bulan-akan-mengelilingi-kabah/

Sasongko, Agung. “UAS: Jadikan Dakwah Sosial Media Sebagai Amal Saleh” oktober 9, 2018. https://www.republika.co.id/berita/dunia-islam/islamnusantara/18/05/15/p8rjeh313-uas-jadikan-dakwah-sosial-media-sebagai-amal-saleh

Sayidatun, Lidya Nisya \& Diah Sofiah. Religiusitas, Kecerdasan Emosional Dan Kenakalan Remaja. JURNAL PSIKOLOGI Volume 7 No. 2, AGUSTUS 2012

Sidiq, Anwar. "Pemanfaatan Instagram Sebagai Media Dakwah (Study Akun @Fuadbakh)". Skirpsi, Fakultas Dakwah Dan Ilmu Komunikasi Universitas Islam Negeri Raden Intan Lampung, 2017.

Soyomukti, Nurani. Pengantar Ilmu Komunikasi, Yogyakarta : Az Ruz Media, 2010

Sugiyono, Metode Penelitian Data Kualitatif dan kuantitatif, Bandung: Alfabeta, 2012 
Suriani, Julis. "Komunikasi dakwah di Era Cyber", Jurnal An-nida' Jurnal Pemikiran Islam, Voloume 41 No. 2, Desember (2017) : 252-262

Tasmara, Toto. Komunikasi Dakwah, Jakarta : Gaya Media Pratama, 1997

"Top 15 Valuable facebook statistic" Agustus 10,2018. https://zephoria.com/top-15-valuablefacebook-statistics/

"UU ITE Baru dan Risiko Hukum Bagi Pengguna Media Sosial." Hukumonline.com. Diakses pada 9 Oktober 2018, https://www.hukumonline.com/berita/baca/It58636cf3cc4d7/uuite-baru-dan-risiko-hukum-bagi-pengguna-media-sosial

Uchjana, Onong. IImu Komunikasi:Teori dan Praktek, Bandung: Rosda Karya, 2009

Wati, Juni Sri Riski. "Dakwah dalam Masyarakat Dunia Maya (Cyber Community): Peluang dan Tantangannya" Jurnal HIKMAH, Vol. VI, No. 01 (2012) : 87-95

"World's Most Literate Nations Ranked" Agustus 10,2018.

https://webcapp.ccsu.edu/?news=1767\&data 